\title{
Determination of HIF1-Ars11549465 Polymorphism in Elite Skiers
}

\section{Ömer KAYNAR ${ }^{1}$, M.Fatih BİLİI' ${ }^{1}$, Canan SERCAN ${ }^{2}$, Korkut ULUCAN ${ }^{2,3}$}

${ }^{1} \mathrm{Muş}$ Alparslan University, School of Physical Education and Sports, Muş, Turkey

2 Üsküdar University of Medical Genetics and Molecular Diagnostic Laboratory, Istanbul, Turkey

${ }^{3}$ Marmara University, Faculty of Dentistry, Department of Medical Biology and Genetics, Istanbul, Turkey

Address Correspondence to Ö. KAYNAR. omer_kaynar49@hotmail.com

\begin{abstract}
Studies in sports genetics have increased nowadays and the identification of genotype and allelic distributions of candidate genes in different athletes has provided important information to sports scientists. One of the candidate genes studied in sports genetics is the hypoxia-inducible factor 1-alpha (HIF1A) gene, which is associated with the endurance phenotype. In our study, we aimed to determine the genotypic and allelic distribution of HIF1A rs11549465 polymorphism in Turkish Elite cross-country athletes. 34 (23 male, 11 female) athletes were included in the study, and $1 \mathrm{cc}$ of blood samples taken for routine analysis after the approval of the ethics committee was used for DNA isolation. The commercial kit was used for DNA isolation and genotyping was performed by Real-time PCR method. The number and percentage of CC, CT and TT genotypes of the HIF1A rs11549465 polymorphism were $24(72.72 \%), 8(24.24 \%)$ and 1 (3.03), respectively. In male skiers CC, CT and TT genotype numbers and percentages were determined as $17(55.51 \%), 4(12.12 \%)$ and $1(3.03 \%)$ respectively. In female, CC and TT genotypes were determined as $7(21.21 \%)$ and $4(12.12 \%)$. We detected no TT genotype in female athletes. When we look at allel numbers, $\mathrm{C}$ allele was determined as $56(84.84 \%)$ and $\mathrm{T}$ allele was determined as $10(15.15 \%)$. This is the first study on HIF1A rs11549465 polymorphism on Turkish elite ski cross-country athletes. The higher prevalence of CC genotype and C allele in the athlete group is similar to the previous studies on different groups of athletes. We believe that this study will be an important reference for further studies.
\end{abstract}

Key words: Sport genetics, cross-country, athletic performance, HIF1-A

\section{INTRODUCTION}

One of the ways to be successful in sport is being talent. Although it is known that sportmen physical, physiological and mental capacities are an important indicator affecting athletic performance, being talent as an individual is a significant factor. Being a talent individual depends on the features such as mental skill and high performance, inborn physical (flexibility, muscular force, body composition) and physiological factors and genetic factors suitable to the sport that he deals with (9). In addition to that, their nourishment, discipline of training and their genetical inclinations with suitable training conditions provide them to be successful in certain branches of sports. In recent years, the effects of a lot of genes on athletic performance in sport have been researched with the help of the human genom project carried into effect.

As a result of these researches it has been stated that genetic features also effect on athletic performance as well as the components such as force, strength, agility, flexibility, nerve-muscle coordination considered to be effective in identifying athletic performance in athletes and it can be indicated as a criteria in even making athletes lead to the sport that they tend to and in their performances $(5,10)$.

The polymorphisms in genes such as especially HIF1-A, ACTN3, ACE and PPAR-A in sports requiring endurance or explosive power have been often a subject of researches.

Hypoxia-inducible factor alpha gene (HIF1-A) as a transcription factor associated with athletic performance and regulating the expression of the genes providing cell adaptation to hypoxia is one of the studied genes in subjects related to genetic and athletic performance (11). HIF1A is localized in 14q23.2. factors (hypoxia inducable factors, HIFs) that can be stimulated in hypoxia conditions provide cells to adapt the hypoxia conditions and also provide athletes to adapt better especially in aerobic exercises. When the oxygenation of cells is reduced, 
they support fulfillment of residual oxygen demand by stimulating glycolisis and angiogenesis (15).

Functional rs11549465 polymorphism on HIF1A causes proline-serine amino acid change in 582nd position of synthesised polypeptide and cytosinethymine transition. In the result of this, stability and transcriptional activity of HIF1A protein are increased and it causes the athletes to develop new adaptations against changing conditions (8).

Cross country is a sport disciplines requiring endurance and high effort performed on skiers. The typical characteristics of high level skiers, which means that their endurance features are good, are their ability to run on skiers with high level performance for a long time. This characteristic of athletes besides it is effective for them to be successful at sport has been stated that it is related to physiological structure and gene factor $(18,16)$.

In generally, Cold weather and in flat and rough country that has high elevation, $1.5 \mathrm{~km}$ sprint $15 \mathrm{~km}, 50 \mathrm{~km}$ and $15+15 \mathrm{~km}$ biathlon in male athletes, and $1.5 \mathrm{~km}, 10 \mathrm{~km}, 30 \mathrm{~km}, 7.5+7.5 \mathrm{~km}$ biathlon in female athletes performed on skis are a sport disciplines requiring high effort and endurance. The most typical characteristics of high level skiers are their ability to sprint for a long time with high level of performance on skis in cold weather and in places where there is high altitude.

When the literature has been examined it has been found out those genetic studies on Cross Country athletes have not been conducted enough. Thus, in this study performed in our country for the first time, it has been aimed to identify HIF1A rs11549465 polymorphism in elite cross-country athletes.

\section{MATERIAL AND METHOD}

\section{Participants}

The most significant characteristic of athletes attended in our study is that they have elite athletes status. When determining elite athletes criteria, " raking among at least top three in Turkish Championship in past two years in his/her own branch and taking part in international tournaments" have been considered. 34 volunteer cross-country athletes in total consisting 23 male and 11 female athlete taken part in National Ski Team camp conducted in Erzincan and Ağrı have attended to our research. Before beginning the study, the document of legal permission has been taken from Chairmanship of Turkish Ski Federation for study to be done. Our study protocol is designated in accordance with Helsinki Decleration and confirmed by Clinical Studies Council of Faculty of Medicine in Atatürk University. Voluntary Consent Form notifying study protocol and outputs has been confirmed by all athletes attended the study before the study.

\section{Athletes' DNA Recovery and Genotyping}

Blood samples for our study have been provided by taking $1 \mathrm{cc}$ of preferic blood taken for routine biochemical analyses into tubes containing EDTA. DNA isolation has been executed by examining user protocols with High Pure PCR Tamplate Preperation Kit(Roche, Germany). Final concentrations of obtained DNAs have been measured with spectrophotometer and sufficient DNA from all samples has been obtained for genotyping. Isolated DNA material has been executed with 7500 Fast Real-Time PCR System (Applied Biosystems) device by using Taqman Genotyping Assays (Applied Biosystems Foster City, CA, USA) genotyping kits. Genotyping processes have been completed by using $10 \mathrm{uL}$ in

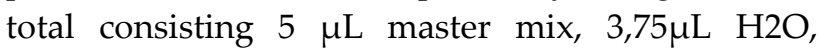
$0,25 \mu \mathrm{L}$ assay and $1 \mu \mathrm{L}(10 \mathrm{ng})$ DNA.

\section{RESULT}

Athletes age average as $25,60 \pm 6,8$ (years), height as $172,00 \pm 6,38(\mathrm{~cm})$ and weight as $72,77 \pm 11,79(\mathrm{~kg})$

have been found. Demographic information about elite athletes has been shown in Table 1.

\begin{tabular}{|c|c|c|c|c|c|}
\hline \multicolumn{2}{|c|}{ Physical Feature [ \pm ss ] } & \multirow{2}{*}{$\begin{array}{l}\text { Education [ n (\%) ] } \\
\text { High School }\end{array}$} & \multicolumn{3}{|c|}{ Number of Level [ $n(\%)$ ] } \\
\hline Age (year) & $25.60 \pm 6.8$ & & $1(5)$ & Turkish Championship & $25(69,44)$ \\
\hline Height (cm) & $172.00 \pm 6.38$ & Undergraduate & $18(90)$ & Balkan Championship & $9(26,47)$ \\
\hline Weight (kg) & $72.77 \pm 11.79$ & Postgraduate & $1(5)$ & & \\
\hline
\end{tabular}


In our cohort study, number and percentages of HIF1ACC,CT and TT genotypes have been found as respectively 24 (\%72.72), 8 (\%24.24) and 1 (3.03). The numbers and percentages of $\mathrm{CC}, \mathrm{CT}$ and TT genotype in male skiers have been identified as respectively 17 (\%55.51), 4 (\% 12.12) and 1 (\% 3.03) while CC and CT genotype and percentages in female skiers have been identified as respectively 7
(\%21.21) and 4 (\% 12.12). TT genotype has not been identified in females. When we look at the number of alleles, C allele has been identified as 56 (\%84.84) while $\mathrm{T}$ allele has been identified as $10(\% 15.15)$ in our cohort. HIF1A genotype and allele frequencies of cross country national team athletes have been summarised in Table 2.

\begin{tabular}{lccccc}
\hline \multicolumn{6}{l}{ Table 2. HIF1Ars11549465 genotype and allele frequencies of cross country national team athletes } \\
\hline \multicolumn{7}{c}{ Genotype } & \multicolumn{5}{l}{ Allele } \\
\hline Groups & CC & CT & TT & C & T \\
\hline Male (n=22) & $17(\% 55.51)$ & $4(\% 12.12)$ & $1(\% 3.03)$ & 38 & 6 \\
Female (n=11) & $7(\% 21.21)$ & $4(\% 12.12)$ & $0(\% 0)$ & 18 & 4 \\
Total $(\mathbf{n = 3 3 )}$ & $24(\% 72.72)$ & $8(\% 24.24)$ & $1(\% 3.03)$ & $56(\% 84.84)$ & $10(\% 15.15)$ \\
\hline
\end{tabular}

\section{DISCUSSION}

Studies in the area of sport genetic have been started by Bouchard et al.(4) who revealed the effects of gens on sportive activity and researched sportive achievements of monozygotic and dizygotic twins in a most comprehensive way and investigated by Montgomery et al. (14). However in the helm of the most effective studies in this area it has been accelerated with the effect of ACTN3 rs1815739 polymorphism yang et al.(17) on sprinter and endurance activities. From this date, studies in this area have been accelerated and the determination of the contributions of new genes to sportive activities has been accelerated as physiological features are identified and with the help of development of new technologies.

HIF1-A protein synthesized by HIF1A gene is a transcription factor that enhances expressions of the other genes having roles in aerobic metabolism and sustains expression as an answer to oxygen stress of the tissues and cells especially. HIF1A rs1154965 Polymorphism on genes provides cells and tissues to be prepared against oxygen stress by effecting to the speed of gene transcription (3).

C allele of polymorphism codes proline amino acid and $\mathrm{T}$ allele called as allele codes serine amino acid. In phenotypic perspective Ahmedov et al. (1) have shown that HIF1A rs11549465 polymorphism is connected with fast type IIX muscle fibre. It has been determined that $\mathrm{T}$ allele also increases the speed of transcription. In our Turkish cross-country athletes cohort study, it has been determined that CC genotype and $\mathrm{C}$ allele in terms of HIF1A rs11549465 polymorphism are higher compared to
TT genotype accepted as polymorphic and rare variant $\mathrm{T}$ allele.

In the study, where 316 elite male endurance athletes from Caucasus and 304 control individual are compared, it has been statistically $(p=0.006)$ determined that $\mathrm{C}$ allele and CC genotype in athletes are higher than the control group (6). This result shows congruity with our cohort results. All the same, in the study (2) where 265 Russian endurance athletes and controls have been examined, the difference between two groups has not been identified $(p>0.05)$.

There are different studies notifying that HIF1A rs11549465 polymorphism has a connection with athletic performance in elite enduring athletes (13). Similarly, it has been identified that the same polymorphism in Russian weight-lifters and wrestlers provides inclination in sportive achievement (1). Similar results have been observed in Polish athletes (12) but not in Israeli sprinters (7).

When examining the studies in literature, it has been observed that the results obtained from HIF1A rs11549465 polymorphism are contradictory. The eventuation of these studies on athletes from different discipline and populations can be asserted as the biggest reason. In our cohort study it has been found out that CC genotype related to endurance and $C$ allele are in high ratio. According to the results that we obtained, we anticipate that related genetic polymorphism has close connection with the endurance feature.

We consider that the eventuation of these analyses on Turkish athletes for the first time will be an important source of information not only in terms of contributing to the literature but also in 
terms of leading next studies to be done. Moreover the implication of HIF1Ars11549465 genotype test as a significant indicator of endurance feature in national team selections with new beginners of biathlon in terms of selecting talented athletes becomes more of an issue.

Note: This study has been supported by Coordinator of Muş Alparslan University Scientific Research Projects (BAP-17- BESYO-4901-01).

\section{REFERENCES}

1. Ahmetov II, Hakimullina AM, Lyubaeva EV. Vinogradova OL and Rogozkin VA. Effect of HIF1A Gene Polymorphism on Human Muscle Performance. Bulletin of Experimental Biology and Medicine, 2008;146,(3): 327-329,

2. Ahmetov II, Williams AG, Popov DV, Lyubaeva EV, Hakimullina AM, Fedotovskaya ON \& Rogozkin VA. The combined impact of metabolic gene polymorphisms on elite endurance athlete status and related phenotypes. Hum Genet. 2009;126:751-61.

3. Berra E, Benizri E, Ginouves A, Volmat V, Roux D, Pouyssegur J. HIF prolylhydroxylase 2 is the key oxygen sensor setting low steady-state levels of HIF- $1 \alpha$ in normoxia. EMBO J, 2003; 22: 4082-4090.

4. Bouchard JR, Thomas J, and Matt McGue. "Genetic and environmental influences on human psychological differences." Journal of neurobiology, 2003; 54.1 4-45.

5. Çorak A, Kapıcı S, Sercan C, Akkoç O, Ulucan K. A pilot study for determination of anxiety related SLC6A4 promoter "S" and "L" alleles in healthy Turkish athletes. Cellular and Molecular Biology, 2017; 63: 29-31.

6. Döring F, Onur S, Fischer A, Boulay MR, Pérusse L, Rankinen T \& Bouchard CA. Common haplotype and the Pro582Ser polymorphism of the hypoxia-inducible factor- $1 \alpha$ (HIF1A) gene in elite endurance athletes. Journal of Applied Physiology, 2010; (108) 6: 1497-1500.

7. Eynon N, Bantingb LK, Ruizc JR, Cieszczykd P, Dyatlove DA, Maciejewska-Karlowskaf A, Sawczukf M, Pushkareve VP, Kulikove LM. ACTN3 R577X polymorphism and teamsport performance: A study involving three European cohorts. Journal of Science and Medicine in Sport, 2014; 17: 102-106.

8. Ivan M, Kondo K, Yang H, Kim W, Valiando J, Ohh M, Salic A, Asara JM, Lane WS, Kaelin WG. HIF $\alpha$ targeted for VHLmediated destruction by proline hydroxylation: implications for O2 sensing. Science, 2001; 292: 464-468.

9. Kaynar Ö and Bilici MF. Analysis of the Talent Selection in Turkish Wrestling. International Journal of Science Culture and Sport, 2017; 5(4):347-355.

10. Korkut Ulucan. Spor Genetiği Açısından Türk Sporcuların ACTN3 R577X Polimorfizm Literatür Özeti. Clin Exp Health Sci 2016; 6(1): 44-47.

11. Lysiak JJ, Kirby JL, Tremblay JJ, Woodson RI, Reardon MA, Palmer LA, Turner TT. Hypoxia-inducible factor-1a is constitutively expressed in murine Leydig cells and regulates 3b-hydroxysteroid dehydrogenase type 1 promoter activity. J. Androl, 2009; 2: 146-156.

12. Maciejewska A, Sawczuk M, Cieszczyk, P, Mozhayskaya IA, \&Ahmetov II. The PPARGC1A gene Gly482Ser in Polish and Russian athletes. Journal of sports sciences, 2012; 30(1): 101113.

13. Mason SD, Rundqvist H, Papandreou I, Duh R, McNulty WJ, Howlett RA \& Johnson RS. HIF-1 in endurance training: suppression of oxidative metabolism. Am J Physiol Regul Integr Comp Physiol,2007; 293: 2059-2069.

14. Montgomery HE, Marshall R, Hemingway H. Human gene for physical performance. Nature, 1998; 393(6682): 221-222.

15. Prior SJ, Hagberg JM, Phares DA, Brown MD, Fairfull L, Ferrell RE, Roth SM. Sequence variation in hypoxiainducible factor 1 alpha (HIF1A): association with maximal oxygen consumption. Physiol Genomics 2003;15: 20-26.

16. Ulucan K, Sercan C, ve Biyıklı T. Distribution of Angiotensin-1 Converting Enzyme Insertion/Deletion and $\alpha$ Actinin-3 Codon 577 Polymorphisms in Turkish Male Soccer Players. Genetics \& Epigenetics, 2015: 71-74.

17. Yang N, Macarthur DG, Gulbin JP. ACTN3 genotype is associated with human elite athletic performance. American Journal of Human Genetics, 2003;73: 627-631.

18. Zilberman-Schapira G, Chen J, Gerstein M. On sports and genes. Recent Patents on DNA \& Gene Sequences Journals, 2012; 6: 180-188. 